\title{
Antimicrobial Activity of Hyptis ovalifolia Towards Dermatophytes
}

\author{
Lúcia KH Souza/ ${ }^{+}$, Cecília MA de Oliveira*, Pedro H Ferri*, \\ Juldásio Galdino de Oliveira Júnior, Ary Henrique de Souza Júnior, Orionalda de Fátima \\ Lisboa Fernandes, Maria do Rosário R Silva
}

\author{
Laboratório de Micologia, Instituto de Patologia Tropical e Saúde Pública *Laboratório de Produtos Naturais, Instituto de \\ Química, Universidade Federal de Goiás, Caixa Postal 131, 74605-050 Goiânia, GO, Brasil
}

The essential oil and the aqueous, hexane and methanolic fractions from Hyptis ovalifolia leaves were evaluated for their antifungal activity in vitro against 60 strains of dermatophytes: 10 strains of Microsporum canis, 10 of $\mathrm{M}$. gypseum, 20 of Trichophyton rubrum and 20 of T. mentagrophytes. The extracts inhibited growth of the dermatophytes tested at different concentrations. The most biologically active was the essential oil from the leaves which inhibited 57 isolates (95\%) at a concentration of $\leq 500 \mu \mathrm{g} / \mathrm{ml}$.

Key words: dermatophytes - Hyptis ovalifolia - antifungal activity

Mycotic infections are probably the most common cause of skin disease in developing countries of tropical regions. Dermatophytosis is the most frequent superficial fungal infection in Brazil. The drugs used against dermatophytosis exhibit several side effects and have limited efficacy (Gupta et al. 1998, Carazo et al. 1999). So that there is a distinct need for the discovery of new safer and more effective antifungal agents. The use of medicinal herbs in the treatment of skin diseases including mycotic infections is an age-old practice in many parts of the world (Irobi et al. 1993). This use has been supported by the isolation of active antifungal compounds from plant extracts (Costa et al. 2000, Silva et al. 2001, Souza et al. 2002, Passos et al. 2002).

Previous reports on the activity of ethanolic extract from leaves of Hyptis ovalifolia against dermatophytes have been reported by Souza et al. (2002). In this study the antifungal activity of the essential oil and the aqueous, hexane, and methanolic fractions from $\mathrm{H}$. ovalifolia leaves against 60 dermatophytes is described.

\section{MATERIALS AND METHODS}

Plant material - Hyptis ovalifolia Benth. (Lamiaceae) was collected in Goiânia, state of Goiás, Brazil and identified by Prof. Heleno Dias Ferreira, Departamento de Botânica, Instituto de Ciências Biológicas, Universidade Federal de Goiás (UFG). Voucher samples were preserved at the herbarium of the UFG.

Preparation of plant extract - The essential oil of $H$. ovalifolia leaves was obtained by steam distillation in a Clevenger-type apparatus for $5 \mathrm{~h}$. The ethanolic extract of dried leaves was partitioned between chloroform and water. The chloroform fraction after evaporation was

${ }^{+}$Corresponding author: Fax: +55-62-215.2057. E-mail: lucki@persogo.com.br

Received 26 May 2003

Accepted 20 August 2003 partitioned between hexane/methanol. The hexane, methanol and aqueous fractions were reduced to dryness and solutions of each as well as of the essential oil were dissolved in dimethyl sulfoxide (DMSO) prepared for subsequent bioassay.

Dermatophyte isolates - The microorganisms used for the biological evaluation were clinical isolates provided by Laboratório de Micologia, Instituto de Patologia Tropical e Saúde Pública, UFG, and identified by standard procedure (Rebell \& Taplin 1970). They were: 10 Microsporum canis, 10 M. gypseum, 20 Trichophyton rubrum and 20 T. mentagrophytes. Sabouraud's dextrose agar at $25^{\circ} \mathrm{C}$ was used to maintain isolates. In antifungal assays, the samples were transferred to potato dextrose agar and maintained for 7 days at $25^{\circ} \mathrm{C}$.

Antifungal assay - The susceptibility test was performed as described by Cáceres et al. (1993), with the following modifications. The extracts were solubilized in DMSO and a two-fold serial dilution was performed in Sabouraud with chloramphenicol and cycloheximide agar medium, to obtain a concentration range of 3.9 to $1000 \mu \mathrm{g} /$ $\mathrm{ml}$, poured into Petri dishes. Thirty seven wells of $3 \mathrm{~mm}$ were opened using a Steers inoculator. To each well $10 \mu \mathrm{l}$ of a dermatophyte suspension were added. This suspension was prepared using $0.85 \%$ sterile physiological saline with Tween $80(0.05 \%)$ and adjusted with a spectrophotometer at $530 \mathrm{~nm}$ to obtain $90 \%$ transmission (Lima et al. 1993). The inoculated plates were then incubated at $25^{\circ} \mathrm{C}$ for 5 days and the minimal inhibitory concentration (MIC) was defined as the lowest concentration that substantially inhibited growth of the microorganism detected visually. Duplicate plates were used for each assay. A growth control of the test strains and a susceptibility standard test using terbinafine (10 $\mu \mathrm{g} / \mathrm{ml})$ as the reference system were performed applying the same technique.

\section{RESULTS}

The results of antifungal assay showed that the essential oil, aqueous, methanolic, and hexane fractions obtained from $H$. ovalifolia leaves possess antifungal activity against the dermatophytes studied (Tables I, II). 
TABLE I

Antifungal activity of different fractions of Hyptis ovalifolia leaves against dermatophyte isolates

\begin{tabular}{|c|c|c|c|c|c|c|}
\hline \multirow{2}{*}{\multicolumn{2}{|c|}{ Fractions }} & \multicolumn{5}{|c|}{ Cumulative number of strains inhibited at concentrations $(\mu \mathrm{g} / \mathrm{ml})$} \\
\hline & & 125 & 250 & 500 & 1000 & not inhibited \\
\hline \multirow{4}{*}{ 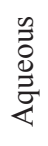 } & M. canis $^{a}$ & 0 & 0 & 6 & 10 & 0 \\
\hline & M. gypseum ${ }^{a}$ & 0 & 0 & 2 & 4 & 6 \\
\hline & T. rubrum ${ }^{b}$ & 0 & 2 & 8 & 10 & 10 \\
\hline & T. mentagrophytes ${ }^{b}$ & 0 & 0 & 0 & 0 & 20 \\
\hline \multirow{4}{*}{$\begin{array}{l}\stackrel{0}{0} \\
\text { O } \\
\text { 苟 } \\
\stackrel{0}{\Sigma}\end{array}$} & M. canis $^{a}$ & 1 & 6 & 8 & 8 & 2 \\
\hline & M. gypseum ${ }^{a}$ & 0 & 2 & 7 & 10 & 0 \\
\hline & T. rubrum ${ }^{b}$ & 3 & 9 & 19 & 19 & 1 \\
\hline & T. mentagrophytes ${ }^{b}$ & 0 & 6 & 16 & 17 & 3 \\
\hline \multirow{4}{*}{ 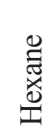 } & M.canis ${ }^{a}$ & 0 & 1 & 2 & 6 & 4 \\
\hline & M. gypseum ${ }^{a}$ & 0 & 0 & 2 & 6 & 4 \\
\hline & T. rubrum ${ }^{b}$ & 0 & 0 & 3 & 10 & 10 \\
\hline & T. mentagrophytes ${ }^{b}$ & 0 & 0 & 3 & 9 & 11 \\
\hline
\end{tabular}

M: Microsporum; T: Trichophyton; $a: \mathrm{n}=10 ; b: \mathrm{n}=20$

TABLE II

Antifungal activity of essential oil of Hyptis ovalifolia leaves against dermatophyte isolates

\begin{tabular}{|c|c|c|c|c|c|c|c|c|c|}
\hline \multirow{2}{*}{$\begin{array}{l}\text { Fraction } \\
\text { tested }\end{array}$} & \multirow[b]{2}{*}{ Dermatophyte $(n=60)$} & \multicolumn{8}{|c|}{ Cumulative number of isolates inhibited at concentrations $(\mu \mathrm{g} / \mathrm{ml})$} \\
\hline & & 7.8 & 15.6 & 31.2 & 62.5 & 125 & 250 & 500 & 1000 \\
\hline \multirow{4}{*}{ 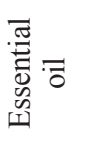 } & M.canis ${ }^{a}$ & 0 & 4 & 0 & 0 & 7 & 9 & 10 & 10 \\
\hline & M. gypseum ${ }^{a}$ & 1 & 2 & 4 & 5 & 9 & 9 & 10 & 10 \\
\hline & T. rubrum ${ }^{b}$ & 2 & 9 & 10 & 13 & 15 & 20 & 20 & 20 \\
\hline & T. mentagrophytes ${ }^{b}$ & 0 & 0 & 0 & 3 & 7 & 19 & 20 & 20 \\
\hline
\end{tabular}

M: Microsporum; T: Trichophyton; $a: \mathrm{n}=10 ; b: \mathrm{n}=20$

The antifungal activity of $H$. ovalifolia leaves for all dermatophytes at the concentration $\leq 1000 \mu \mathrm{g} / \mathrm{ml}$ showed that the aqueous fraction inhibited the growth of $40 \%$ $(24 / 60)$, the methanolic fraction of $90 \%(54 / 60)$, the hexane fraction of $51.7 \%(31 / 60)$, while the essential oil inhibited $100 \%$ of 60 dermatophytes tested.

The susceptibility of dermatophyte species towards the different fractions differed. T. rubrum was the most susceptible species to most fractions tested. Three isolates of this species were inhibited by the methanolic fraction at $125 \mu \mathrm{g} / \mathrm{ml}$ and two isolates were inhibited by the essential oil at $7.8 \mu \mathrm{g} / \mathrm{ml}$. T. mentagrophytes was the least susceptible of the dermatophytes. The aqueous fraction had no activity against this species, while the essential oil, on average, the most active against all dermatophytes tested only showed growth inhibition for this species in high concentration. Terbinafine, used as control inhibited all dermatophytes at $10 \mu \mathrm{g} / \mathrm{ml}$.

\section{DISCUSSION}

The results obtained in our study show wide spectrum antifungal properties for the hexane, methanolic, and aqueous fractions and for the essential oil of $H$. ovalifolia leaves. In the earlier studies Souza et al. (2002) verified that the crude extract of this plant inhibited growth of dermatophyte isolates at concentrations between 15.6 to
$1000 \mu \mathrm{g} / \mathrm{ml}$. Paula et al. (2001) showed that a crude extract of the leaves of this plant has activity against Cryptococcus neoformans, one of the most important fungi responsible for meningitis in HIV patients.

The broad spectrum of activity of the methanolic fraction which inhibited $90 \%$ of dermatophytes isolated is only surpassed by that of the essential oil which inhibited the growth of all dermatophytes tested at concentration $\leq 1000 \mu \mathrm{g} / \mathrm{ml}$. The broad activity could be explained by essential oil composition. The leaves of $H$. ovalifolia investigated by GC/MS showed that the main constituent representing $60 \%$ of the essential oil isolated by column chromatography was identified by spectral methods as (R)-6-[(Z)-1-heptenyl]-5,6-dihydro-2H-piran2-one.

The antifungal activity of essential oils from other plants is well known. The essential oil of Eugenia dysenterica shows good activity against $C$. neoformans (Costa et al. 2000) and H. suaveolens is active against Candida albicans (Asekun et al. 1999). Thus the broad spectrum of antifungal activity is consistent with results obtained by several researchers for other essential oils which have shown protection action against both bacterial and fungal pathogens (Janssen et al. 1987).

The variation of susceptibility in vitro from one species to another is evident from the results. T. rubrum 
the commonest etiological agent of dermatophytosis in Goiânia (Costa et al. 1999, 2002) was the most susceptible dermatophyte. This species is the cause of between 80 $90 \%$ of all chronic and recurrent infections (TorresRodrigues et al. 1998). The fact that current dermatophytosis therapy can cause considerable side-effects and adverse effects in some patients (Gupta et al. 1998), renders plant-derived compounds of special interest because they are generally safer and often more effective substitutes for the synthetically produced antimicrobial agents.

The essential oil of $H$. ovalifolia leaves is thus of particular interest as a source of new anti infective agents for dermatophytic infections in humans. An investigation on a larger scale would allow a better evaluation of the susceptibility phenomena of dermatophytes to essential oil of H. ovalifolia.

\section{REFERENCES}

Asekun OT, Ekundayo O, Adeniyi BA 1999. Antimicrobial activity of the essential oil of Hyptis suaveolens leaves. Fitoterapia 70: 440-442.

Cáceres A, López B, Juárez X, Aguila J, García S 1993. Plants used in Guatemala for the treatment of dermatophytic infections. 2. Evaluation of antifungal activity of seven American plants. J Ethnopharmacol 40: 207-213.

Carazo JLS, Losada LO, Sanjuan VP 1999. Tratamiento actual de las micose superficiales. Rev Iberoam Micol 16: 26-30.

Costa M, Passos XS, Souza LKH, Miranda ATB, Lemos JA, Oliveira Jr JG, Silva MRR 2002. Etioliogia e epidemiologia das dermatofitoses em Goiânia, GO, Brasil. Rev Soc Bras Med Trop 35: 19-22.

Costa TR, Costa MR, Silva MV, Rodrigues AB, Fernandes OFL, Soares AJ, Silva MRR 1999. Etiologia e epidemiologia das dermatofitoses em Goiânia, GO, Brasil. Rev Soc Bras Med Trop 35: 367-371.

Costa TR, Fernandes OFL, Santos SC, Oliveira CMA, Lião LM, Ferri PH, Paula JRP, Ferreira HD, Sales HN, Silva MRR 2000. Antifungal activity of volatile constituents of Eugenia dysenterica leaf oil. JEthnopharmacol 72: 111-117.
Gupta AK, Lynde CW, Lauzon GJ, Mehlmauer MA, Braddock SW, Miller CA, Del Rosso JQ, Shear NH 1998. Cutaneous adverse effects associated with terbinafine therapy: 10 case reports and a review of the literature. Br J Dermatol 138: 529-532.

Irobi ON, Darambola SO 1993. Antifungal activities of crude extract of Mitracarpus villosus (Rubiaceae). J Ethnopharmacology 40: 137-140.

Janssen AM, Scheffer JJ, Baerheim-Svendsen A 1987. Antimicrobial activities of essential oils: a 1976-1986 literature review. Aspects of the test methods. Planta Medica 53: 395-398.

Lima EO, Gompertz OF, Giesbrecht AM, Paulo MQ 1993. In vitro antifungal activity of essential oils obtained from officinal plants against dermatophytes. Mycoses 36: 333336.

Passos XS, Santos SC, Ferri PH, Fernandes OFL, Paula TF, Garcia ACF, Silva MRR 2002. Atividade antifúngica de Caryocar brasiliensis (Caryocaraceae) sobre Cryptococcus neoformans. Rev Soc Br Med Trop 35: 623-627.

Paula TF, Garcia ACF, Oliveira CMA, Martinez RC, Silva MRR 2001. Propriedades antifúngicas de Hyptis ovalifolia sobre Cryptococcus neoformans. Resumo dos Anais do XIII Encontro Científico dos Acadêmicos de Medicina, p. 21.

Rebell G, Taplin D 1970. Dermatophytes, Their Recognition and Identification, University of Miami Press, Coral Gables, Florida.

Silva MV, Costa TR, Costa MR, Ferreira EC, Fernandes OFL, Santos SC, Lião LM, Ferri PH, Paula JR, Ferreira HD, Silva MRR 2001. Growth inhibition effect of Brazilian cerrado plant extracts on Candida species. Pharm Biol 39: 138141.

Souza LKH, Oliveira CMA, Ferri PH, Santos SC, Oliveira Junior JG, Miranda ATB, Lião LM, Silva MRR 2002. Antifungal properties of Brazilian Cerrado plants. Brazil J Microbiol 33: 247-249.

Torres-Rodrigues JM, Madrenys-Brunet N, Urrea-Arbeláez A, López-Jodra O 1998. Terbinafina por via oral en el tratamiento de la tinea unguium de los pies. Eficacia entre $12 \mathrm{y}$ 14 semanas de tratamiento. Rev Iberoam Micol 15: 160162 . 